\title{
Psychological Status of Primary Medical Staff During the COVID-19 Outbreak [Letter]
}

\author{
Heru Santoso Wahito Nugroho (D) ' \\ Angelito Estoesta Alvarado ${ }^{2}$ \\ Myrna A Mercado ${ }^{3}$ \\ 'Department of Health, Poltekkes \\ Kemenkes Surabaya, Surabaya, Indonesia; \\ ${ }^{2}$ College of Nursing, Isabela State \\ University, Echague, Philippines; ${ }^{3}$ School \\ of Nursing, Mountain View College, \\ Valencia City, Philippines
}

\section{Dear editor}

We have looked closely at the article on factors of psychological status of primary medical staff during the COVID-19 outbreak. In bivariate-analysis, marriage was correlated with all mental health measures (SAS, DAS and MQSPHE), age was correlated with MQSPHE, education was correlated with one aspect of MQSPHE, namely hypochondriasis, while gender was not correlated with mental health. However, at multivariate-analysis, only marriage was proven to be a factor of mental health. ${ }^{1}$ Then the questions arise: 1) Is it true that age, education and gender are not factors of mental health? 2) Could it be that these three are indirect factors of mental health?

In multivariate-analysis, the authors used logistic-regression test to prove simultaneous effect of the four factors, and only marriage was proven as a factor of mental health; whereas in the previous stage (bivariate-analysis), the authors have proven that age and education were also correlated with mental health. This indicates that age and education are actually a factor of mental health, although only as an indirect factor. Thus, it is necessary to carry out further analysis to prove whether age, education and gender are indirect factors of mental health. In this case, the appropriate method to use is path-analysis, ${ }^{2}$ for example using the following alternative pathways:

1. Age $\rightarrow$ marriage $\rightarrow$ mental health.

2. Education $\rightarrow$ marriage $\rightarrow$ mental health.

3. Gender $\rightarrow$ marriage $\rightarrow$ mental health.

For example, it is assumed that age affects marriage, then marriage affects mental health, as well as for other paths; and the authors can modify it.

Based on the paths, and referring to similar problems, ${ }^{3,4}$ we suggest that the authors carry out further analysis using path-analysis with Smart-PLS program because all independent variables are categorical data. ${ }^{2}$ This method is expected to prove the status of age, education and gender as indirect factors of mental health of medical staff during the COVID-19 outbreak.

\section{Disclosure}

The authors report no conflicts of interest related to this communication.
Correspondence: Heru Santoso Wahito Nugroho Pucang Jajar Tengah-56, Surabaya, Indonesia

Tel +6282I42259360 Email heruswn@poltekkesdepkes-sby.ac. 


\section{References}

1. Wang S, Gao R, Li R, Wu G. Psychological status and correlated factors of primary medical staff during the COVID-19 outbreak in Hefei City, China. J Multidiscip Healthc. 2021;14:751-756. doi:10.2147/JMDH.S289336

2. Garson GD. Partial Least Squares: Regression and Structural Equation Models. Asheboro: Statistical Associates Publishing; 2016.

3. Nugroho HSW, Suparji S, Martiningsih W, Suiraoka IP, Acob JRU, Sillehu S. A response to "effect of integrated pictorial handbook education and counseling on improving anemia status, knowledge, food intake, and iron tablet compliance among anemic pregnant women in Indonesia: a quasi-experimental study" [Letter]. J Multidiscip Healthc. 2020;13:141-142. doi:10.2147/JMDH.S247401
4. Susatia B, Martiningsih W, Nugroho HSW. A response to "prevalence and associated factors of musculoskeletal disorders among cleaners working at Mekelle University, Ethiopia" [Letter]. J Pain Res. 2020;13:2707-2708. doi:10.2147/JPR.S281683

Dove Medical Press encourages responsible, free and frank academic debate. The content of the Journal of Multidisciplinary Healthcare 'letters to the editor' section does not necessarily represent the views of Dove Medical Press, its officers, agents, employees, related entities or the Journal of Multidisciplinary Healthcare editors. While all reasonable steps have been taken to confirm the content of each letter, Dove Medical Press accepts no liability in respect of the content of any letter, nor is it responsible for the content and accuracy of any letter to the editor.

Journal of Multidisciplinary Healthcare

Dovepress

\section{Publish your work in this journal}

The Journal of Multidisciplinary Healthcare is an international, peerreviewed open-access journal that aims to represent and publish research in healthcare areas delivered by practitioners of different disciplines. This includes studies and reviews conducted by multidisciplinary teams as well as research which evaluates the results or conduct of such teams or healthcare processes in general. The journal covers a very wide range of areas and welcomes submissions from practitioners at all levels, from all over the world. The manuscript management system is completely online and includes a very quick and fair peer-review system. Visit http://www.dovepress.com/testimonials. php to read real quotes from published authors. 